\title{
Effects of sand burial and overstory tree age on seedling establishment in coastal Pinus thunbergii forests in the northern Shandong Peninsula, China
}

\author{
by Peili Mao ${ }^{1,3}$, Hongxiang Mu², Banghua Cao ${ }^{1, *}$, Yuhong Liư,3, Zhaofei Fan ${ }^{4}$ and Shumei Wang ${ }^{1}$
}

\begin{abstract}
Coastal Pinus thunbergii (Japanese black pine) forests in the northern Shandong Peninsula of China recently experienced widespread natural regeneration failure. This study identifies critical factors that affect natural regeneration of $P$. thunbergii. Seeds from trees of various ages (13-32 years) were used to investigate the effects of age and burial depth in sand on germination and seedling establishment. Results show that seed density in $2-5 \mathrm{~cm}$ soil decreased with increased distance from the shoreline. Sand burial decreased seed germination but did not affect the relative growth rate of seedlings at depths from 0.5 to $3 \mathrm{~cm}$. Germination, leaf mass ratio, and relative growth rates were higher with seedlings originating from older trees, all of which enhanced seedling resistance to sand burial. Tree age and seed burial were found to be determining factors for natural regeneration of the coastal $P$. thunbergii forest. Silvicultural treatments that promote quality of seed sources and mitigation of sand burial can be used in the future to improve the regeneration of these coastal forests.
\end{abstract}

Keywords: coastal forest, seed germination, biomass allocation, relative growth rate, seedling establishment

\section{RÉSUMÉ}

Les forêts côtières de Pinus thunbergii (pin noir du Japon) situées dans la péninsule septentrionale de du Shandong ont affiché été victimes dernièrementrécemment d'importants échecs de la régénération naturelle. Cette étude identifie les facteurs déterminants les plus importants qui affectent de la régénération naturelle du $P$. thunbergii. On a utilisé desLes semences provenant d'arbres de différents âges (13-32 ans) ont été utilisées dans le but de dpour 'étudier les effets de lâge et de la profondeur de lensevelissement lenfouissement dans le sable sur la germination et létablissement des semis. Les résultats indiquent que la densité de semences par dans 2 à $55 \mathrm{~cm}$ de sol diminuait avec laccroissement une augmentation de la distance par rapport au du rivage. L'ensevelissement dans le sable a réduit le taux de germination, mais na pas eu d'effet sur le taux relatif de croissance des semis retrouvés entre 0,5 et $33 \mathrm{~cm}$. La germination, le ratio de masse foliairefeuillage/masse et les taux relatifs de croissance ont été plus élevés dans le cas des semis provenant d’arbres plus âgés, tous contribuant à accroître la résistance des semis à lensevelissement l'enfouissement dans le sable. Il sest avéré que lLâge des arbres et l'ensevelissement lenfouissement des semences avaient une influence déterminante sur ont été identifiés comme étant les facteurs déterminants de la régénération naturelle des forêts de $P$. thunbergii. Les traitements sylvicoles qui favorisent la qualité des sources de semences et l'atténuation de l'enfouisevelissement dans le sable pourront être utilisés à lavenir peuvent être utilisés dans l’avenir pour améliorer la régénération de ces forêts côtières.

Mots clés : forêt côtière, germination des semences, allocation de la biomasse, taux relatif de croissance, établissement des semis

\section{Introduction}

Sand burial is the most important selective force driving the distribution and composition of vegetation in coastal sand dune communities and can remarkably influence all aspects of the plant and soil micro-environment, such as vegetation structure, soil temperature, soil moisture, and oxygen levels (Chen and Maun 1999). Burial depth has been demonstrated to have an effect on seed germination (Zhang and Maun 1994, Chen and Maun 1999, Li et al. 2007, Guo et al. 2010, Liu et al. 2011, Redondo-Gómez et al. 2011, Zhu et al. 2014). For example, the highest seedling emergence for wildrye occurred at a 1-cm depth (Zhu et al. 2014), whereas it was 2$\mathrm{cm}$ for Pitcher's thistle (Chen and Maun 1999). Seeds buried at appropriate depths may have higher germination rates than those on the surface (Chen and Maun 1999, Guo et al. 2010, Liu et al. 2011, Zhu et al. 2014). However, excessive burial may prevent germination and subsequent seedling survival. Several authors report that seeds that do not germinate in sand become dormant, especially at deeper depths and form a seed bank, among which a large proportion of seeds die

\footnotetext{
${ }^{1}$ Key Laboratory of Agricultural Ecology and Environment, Shandong Agricultural University, Taian 271018, P.R. China

${ }^{2}$ College of Forestry, Agricultural University of Hebei, Baoding, 071000, P.R. China

${ }^{3}$ Key Laboratory of Coastal Zone Environmental Processes and Ecological Remediation, Yantai Institute of Coastal Zone Research (YIC), Chinese Academy of Sciences (CAS); Shandong Provincial Key Laboratory of Coastal Zone Environmental Processes, YICCAS, Yantai 264003 ${ }^{4}$ School of Forestry and Wildlife Science, Auburn University, Auburn, AL 36849 USA

${ }^{5}$ Key Laboratory of Integrated Regulation and Resource Development on Shallow Lake of Ministry of Education,College of Environment, Hohai University, Nanjing 210098, P. R. China

*Corresponding author Banghua Cao, E-mail: caobanghua@126.com
} 
(Chen and Maun 1999, Zhu et al. 2009, Guo et al. 2010). Similarly, seedlings are also tolerant to partial burial in sand but mortality increases with complete burial (Maun 1994, Shi et al. 2004, Zheng et al. 2012). Thus, the adaptive ability of sand dune species to withstand sand burial is an important natural regeneration topic of coastal sand dune forest ecosystems.

In a frequently disturbed environment such as coastal dune communities, one vital trait for a species to establish is the timing and rate of seed germination (Cendán et al. 2013). Out of many factors including sand burial, tree age is one of the important factors that may have significant effects on seed germination and seedling establishment. Sorbus torminalis (L.) Crantz. (30 cm DBH class; Espahbodi et al. 2007), Pinus pinea L. (58 cm DBH class; (Ganatsas et al. 2008) and Pinus. echinata Mill. Acc. (33 cm DBH class; Grayson et al. 2002) from medium-aged trees showed the best germination rates ( $43 \%, 98 \%$ and $94 \%$, respectively) even though the optimal age for seed quality might vary with species. In another study, seeds collected from 43-year-old maritime pines showed longer mean germination times than from 13-year-old trees (Alvarez et al. 2005). However, no significant relationships were identified between tree age, seed germination and seedling biomass in maritime pine and shrubby rockrose (Connor and Lanner 1991, Müller et al. 2014). Evidently, the effect of tree age on seed germination and seedling establishment varies with species. The underlying physiological mechanisms remain unknown for many species.

Pinus thunbergii Parl. forests are the most important coastal protection forests in the Japanese islands and Shandong peninsula, China. They provide multiple benefits in mitigating the effects of natural disasters, stabilizing shorelines and sustaining biodiversity (Taniguchi et al. 2007, Hayasaka et al. 2009, Zhu et al. 2012). Because of the harsh environment, coastal forests are vulnerable to disturbances. Large scale even-aged regeneration methods and thinning to regenerate these forests were forbidden in Chinese coastal zones in order to maintain their protective functions (Zhu et al. 2003, Taniguchi et al. 2007, Hayasaka et al. 2009). However, this ban has led to high stem densities and low light intensities which greatly inhibit natural regeneration of the light-demanding $P$. thunbergii seedlings. Therefore, understanding the effect of potential limiting factors including soil seed banks, sand burial and tree age have been recognized as a critical issue to natural regeneration of $P$. thunbergii forests. In this study, the seed bank of the coastal species was investigated in the field and a subsequent nursery experiment on germination and seedling establishment was conducted to evaluate: (1) whether seed dispersal was influenced by sand burial; (2) whether there were significant effects of burial depth and tree age on germination and seedling growth; and, (3) which factors were critical to germination and growth. Results from this study will provide not only an improved understanding of factors related to natural regeneration of $P$. thunbergii, but will also help prescribe viable solutions to regenerate this vulnerable forest.

\section{Materials and Methods \\ Study area}

The study was carried out at a coastal $P$. thunbergii forest in northern Shandong Peninsula, China $\left(37^{\circ} 27^{\prime} 15^{\prime} \mathrm{N}, 121^{\circ} 41^{\prime}\right.$ $57^{\prime}$ E) (Fig. 1). The site has a warm temperate continental monsoon climate with an annual rainfall of $760 \mathrm{~mm}$ and mean annual temperature of $11.5^{\circ} \mathrm{C}$. The soil is classed as sandy with low organic matter content (less than 1\%). The stand was planted in the early 1970s and a density of 3000 trees per ha and a canopy coverage of 0.7 were maintained. Average height and diameter at breast height (DBH) was $4.9 \mathrm{~m}$ and $7.0 \mathrm{~cm}$, respectively. The understory vegetation is simple and consists primarily of four shrub species, indigo bush (Amorpha fruticosa L.), chastetree (Vitex trifolia L. var. simplicifolia Cham.), shrubby bush clover (Lespedeza bicolor Turcz.) and multiflora rose (Rosa multiflora Thunb.). The ground cover consists of several grass and sedge species, including Carex rigescens (Franch.) V. Krecz., Corispermum stenolepis Kitag., Imperata cylindrical (L.) Beauv. var. Major. saltbush (Atriplex sibirica L.), and black nightshade (Solanum nigrum L.).

\section{Sampling of the soil seed bank}

The soil seed bank was examined in August 2007 using three transects at $200 \mathrm{~m}$ intervals set perpendicular to the shoreline.

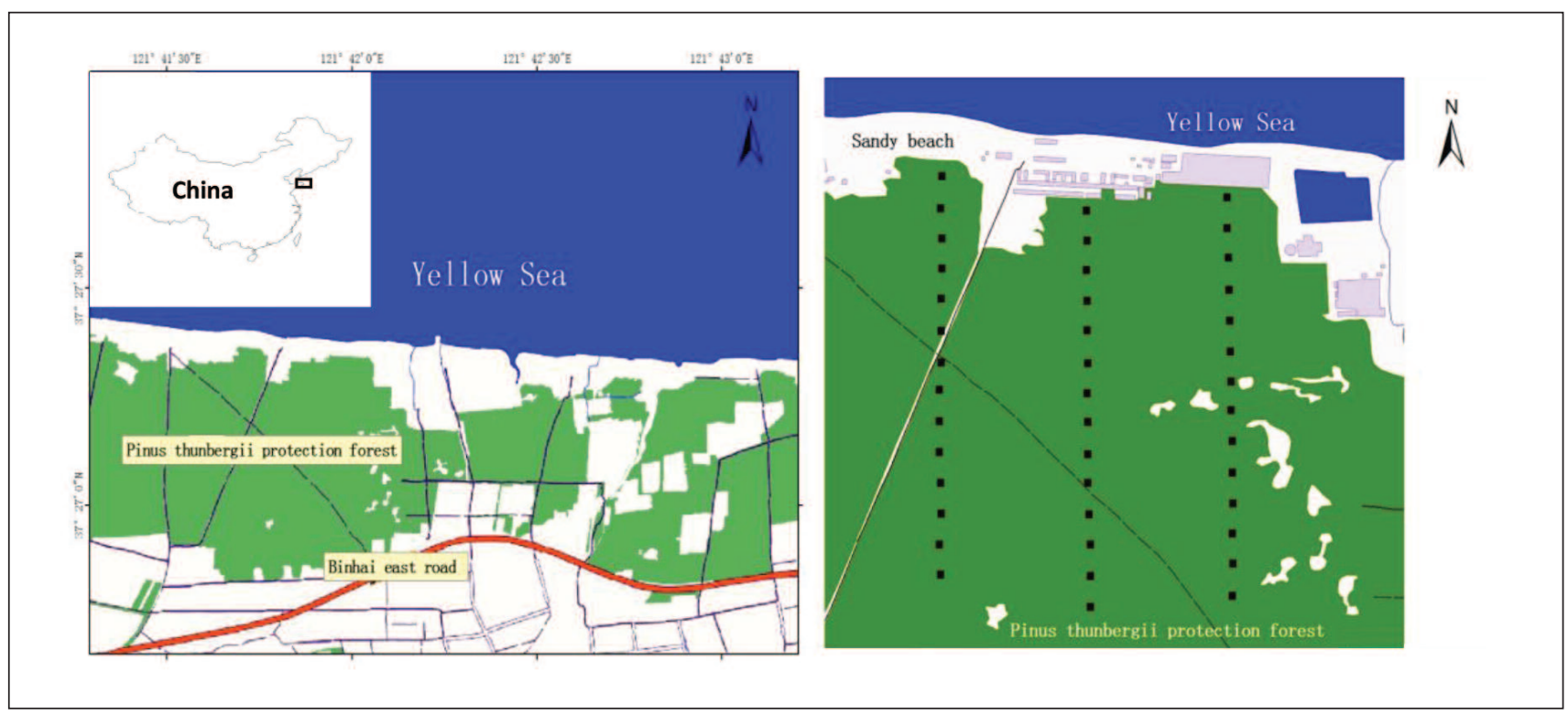

Fig.1. Location of sampling sites of coastal Pinus thunbergii forests in the northern Shandong Peninsula, China. 
Fourteen $100 \mathrm{~m}^{2}$ plots $(10 \mathrm{~m} \times 10 \mathrm{~m})$ were established at intervals of $50 \mathrm{~m}$ along each transect. In each plot, five soil samples were collected randomly using a $7-\mathrm{cm}$ diameter cutting ring and separated into two layers $(0-2 \mathrm{~cm}$ and $2-5 \mathrm{~cm}$ with fresh weights of $102 \pm 2.0 \mathrm{~g}$ and $153 \pm 2.4 \mathrm{~g}$, respectively) in which most seeds were buried. The soil within each layer was mixed, stones and litter removed, and soil samples placed in sealed bags for seed determination.

Table 1. Characteristics of $P$. thunbergii mother trees for seed collection

\begin{tabular}{lccc}
\hline Age classes & $\begin{array}{c}\text { Diameter at } \\
\text { breast height } \\
(\mathbf{c m})\end{array}$ & $\begin{array}{c}\text { Height } \\
(\mathbf{m})\end{array}$ & $\begin{array}{c}\text { Tree age } \\
\text { (years })\end{array}$ \\
\hline Young & $9.55-12.74$ & $6.1-7.3$ & $13-17$ \\
Intermediate & $12.89-15.92$ & $6.5-9.2$ & $18-23$ \\
Mature & $16.56-19.11$ & $6.8-9.8$ & $24-32$ \\
\hline
\end{tabular}

\section{Cone and seed collection}

Cones were collected from three age classes (13-17 years, 18-23 years and 24-32 years) in stands with densities of 1600-2700 trees per ha in late September of 2008 (Table 1). Tree age was computed based on the age-diameter relationship in equation 1 , which was suitable for these source trees (Xu et al. 2003).

$$
\text { (1) } \mathrm{A}=10 \mathrm{ln}\left(1-0.3134 \mathrm{D}^{0.3789}\right)
$$

Where $D$ is diameter at breast height $(\mathrm{cm})$ and $A$ is age (years). A sample of 10-15 individuals in each age class was selected. Five to ten cones were randomly collected from each tree and air-dried for four months until open. Seeds were collected and stored for use in the germination experiment.

\section{Seed germination}

Germination was carried out at the nursery of the Forestry Bureau of Laishan District in Yantai, Shandong Province. A completely randomized factorial design was used to test the effect of tree age and burial depth on germination and biomass growth. Seeds collected from trees in each of the three age classes: young (13-17 years), intermediate (18-23 years) and mature (2-432 years) were sowed at depths of $0.5,1.0,3.0$ and $5.0 \mathrm{~cm}$ in plastic pots filled with sand taken from where cones were collected (Table 1). The sand was sieved to remove debris and any seeds before use. To calculate the sample mean and variance of the germination rate, 20 seeds were sown in each pot and each treatment replicated five times.

During the germination period (4 December 2009-28 April 2010), the minimum and maximum temperatures in the tunnel where the plastic pots were placed varied from $-6{ }^{\circ} \mathrm{C}$ to $34{ }^{\circ} \mathrm{C}$. All pots were well-watered, and after the first seed germinated, germination was assessed every day. The germination rate $(\mathrm{Gr} \%)$ and mean germination time (MGT in days) were calculated. Gr was calculated as the ratio between the number of germinated seeds at a given time and the number of seeds sown. MGT was calculated as follows (Raccuia et al. 2004):
(2) $\mathrm{MGT}=\sum(D n) / \sum_{n}$

Where $\mathrm{D}$ is the number of days from the beginning of the test, and $\mathrm{n}$ is the number of seeds which germinated on day $\mathrm{D}$. MGT at the 5-cm depth was not calculated due to small number of seeds germinating.

At the end of the experiment (28 April 2010), five randomly selected seedlings were removed from each pot and washed free of sand. Each seedling was divided into leaf, stem, and root components and dried at $75{ }^{\circ} \mathrm{C}$ for $48 \mathrm{~h}$. Dry biomass of leaf, stem and root was weighed using an electronic balance ( $0.1 \mathrm{mg}$ accuracy). Individual seedling biomass (leaf + stem + root mass, g), leaf mass ratio (LMR, leaf mass/seedling biomass, $\mathrm{g} \mathrm{g}^{-1}$ ), stem mass ratio (SMR, stem mass/seedling biomass, $\left.\mathrm{g} \mathrm{g}^{-1}\right)$, root mass ratio ( $\mathrm{RMR}$, root mass/seedling biomass, $\mathrm{g} \mathrm{g}^{-1}$ ) and root/shoot ratio (RSR, root mass/(leaf + stem biomass)) were calculated.

\section{Seedling growth}

Three seedlings with similar heights were retained in each pot; heights and diameters at the surface were measured on 1 May 2010. Heights and diameters were remeasured at the end of the experiment on 30 December 2010. During the experiment, no mortality occurred. The relative height growth rate $\left(R_{G} R_{H}\right)$ and relative diameter growth rate $\left(R_{\mathrm{D}}\right)$ were calculated with equations (3) and (4), respectively.

(3) $\mathrm{RGR}_{\mathrm{H}}=\left(\operatorname{lnH}_{2}-\ln \mathrm{H}_{1}\right) /\left(\mathrm{T}_{2}-\mathrm{T}_{1}\right)$

(4) $\mathrm{RGR}_{\mathrm{D}}=\left(\operatorname{lnD}_{2}-\ln \mathrm{D}_{1}\right) /\left(\mathrm{T}_{2}-\mathrm{T}_{1}\right)$

$\mathrm{RGR}_{\mathrm{H}}$ is relative height growth rate $\left(\mathrm{cm} \mathrm{cm}^{-1} \mathrm{~d}^{-1}\right)$; $\mathrm{RGR}_{\mathrm{D}}$ relative diameter growth rate $\left(\mathrm{mm} \mathrm{mm}^{-1} \mathrm{~d}^{-1}\right) ; \mathrm{H}_{1}$ and $\mathrm{H}_{2}$ are seedling heights $(\mathrm{cm})$ at initial and harvest periods; respectively; $\mathrm{D}_{1}$ and $\mathrm{D}_{2}$ are seedling diameters $(\mathrm{cm})$ at initial and harvest periods, respectively; $\mathrm{T}_{2}-\mathrm{T}_{1}$ is the duration of the experiment (days).

\section{Data analysis}

Simple linear regression was used to analyze the change of seed density in the soil of $0-2 \mathrm{~cm}$ (top layer) and $0-5 \mathrm{~cm}$ (top and bottom layers $(2-5 \mathrm{~cm})$ combined), while quantile regression was applied to analyze the change of seed density in the soil of $2-5 \mathrm{~cm}$ (bottom layer) and the ratio of soil seed density in the top and bottom layers with the distance from the shoreline. Instead of predicting conditional means as simple linear regression does, quantile regression predicts a set of predetermined conditional quantiles or percentiles $(95 \%$, $75 \%$ and $50 \%$ ) with the herteroscedastic seed density data (Fig. 2). Effects of burial depth and tree age on seed germination rate (Gr), mean germination time (MGT), seedling biomass, and allometric growth (LMR, SMR, RMR, $\mathrm{RGR}_{\mathrm{H}}$ and $\mathrm{RGR}_{\mathrm{D}}$ ) were first tested using two-way ANOVA as specified in model (5):

(5) $Y_{i j k}=\mu+A_{i}+B_{j}+(A B)_{i j}+\varepsilon_{i j k}$

Where $\mathrm{Y}_{\mathrm{ijk}}$ represents the response variable (Gr, MGT, LMR, SMR, RMR, RGRH and RGRD) from the $i^{\text {th }}(i=1,2,3)$ age class, $\mathrm{j}^{\text {th }}(\mathrm{j}=1,2,3,4)$ burial depth and $\mathrm{k}^{\text {th }}(\mathrm{k}=1,2,3,4,5)$ replication, $\mu$ is the grand mean, $A_{i}$ is the tree age effect, $B_{j}$ is the bur- 

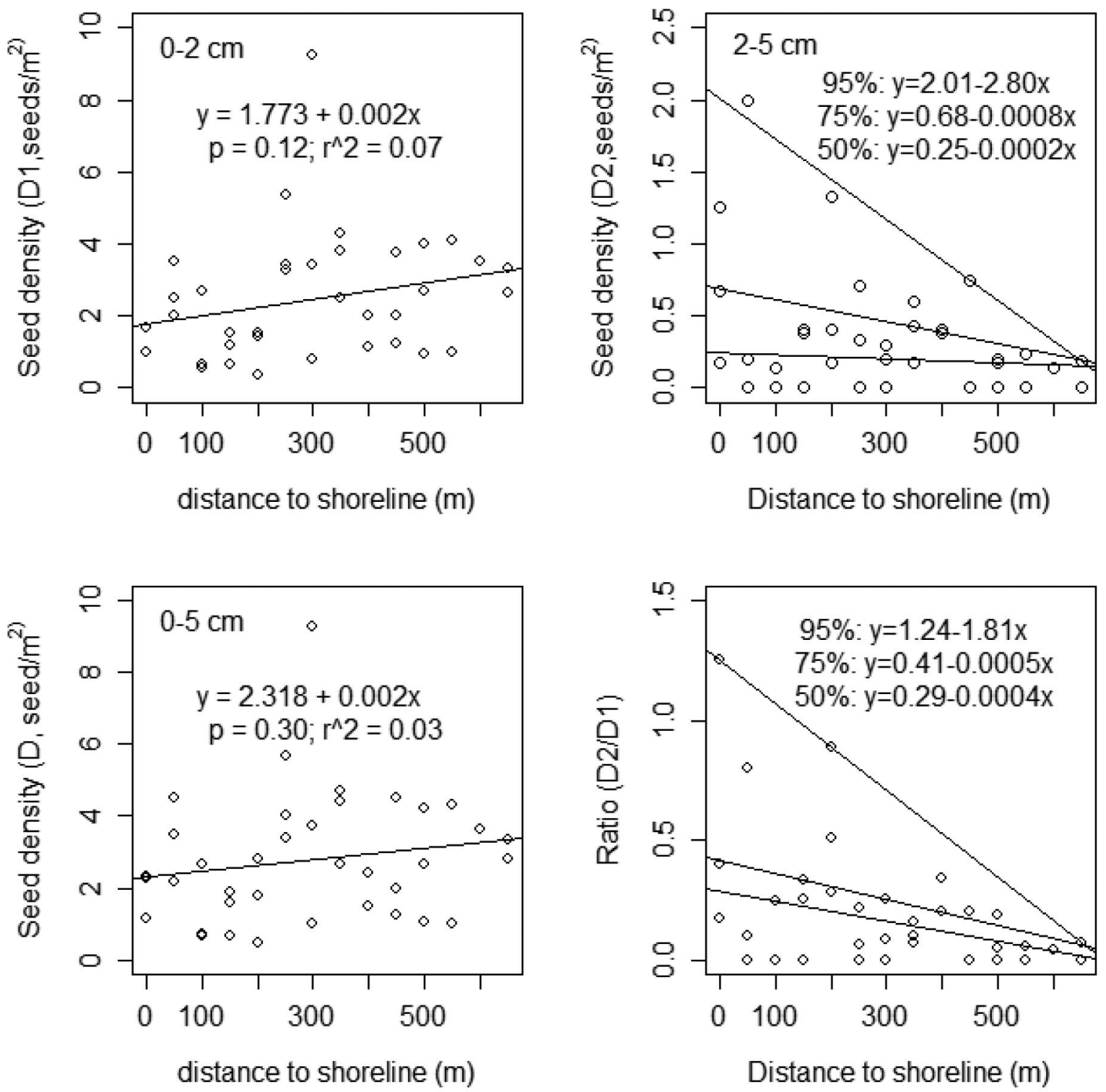

Fig.2. Simple linear regression and quantile regression models that show the changes of soil seed density of $P$. thumbergii with the distance to the shoreline.

ial depth effect, $(A B)_{i j}$ is the interaction of tree age and burial depth and $\varepsilon_{\mathrm{ijk}}$ is the random error. With significant ANOVA tests, post-hoc least-significant difference (LSD) multiple comparisons were further conducted to compare treatment means. Simple linear regression and quantile regression was conducted using the R packages quantreg and stats and other statistical analyses were conducted in the SPSS for Windows 13.0 (SPSS, Chicago, IL, USA) with the statistical significance level set at $\mathrm{p}=0.05$.

\section{Results}

Seed distribution patterns in soil banks

Soil seed density of $P$. thunbergii in the $0-2 \mathrm{~cm}$ layer and in the entire sampling depth $(0-5 \mathrm{~cm})$ increased linearly with the distance from the shoreline, but this positive association was not statistically significant $\left(\mathrm{p}>0.1\right.$ and $\left.\mathrm{R}^{2}<0.1\right)$ due to a large variation in seed density (Fig. 2). As shown by the quantile regression, seed density in the $2-5 \mathrm{~cm}$ layer decreased drastically with the distance from the shoreline, although large variations existed within the distance to the shoreline $<200 \mathrm{~m}$. A similar pattern was found with the ratio of seed density between the $2-5 \mathrm{~cm}$ and $0-2 \mathrm{~cm}$ layers, indicating burial in sand may have more severe effect on soil seed banks at sites near the shoreline.

\section{Seed germination}

Both burial depth and tree age showed significant differences in $\mathrm{G}_{\mathrm{r}}$ and MGT (Fig. 3, Table 2). $\mathrm{G}_{\mathrm{r}}$ showed a decreased trend, 


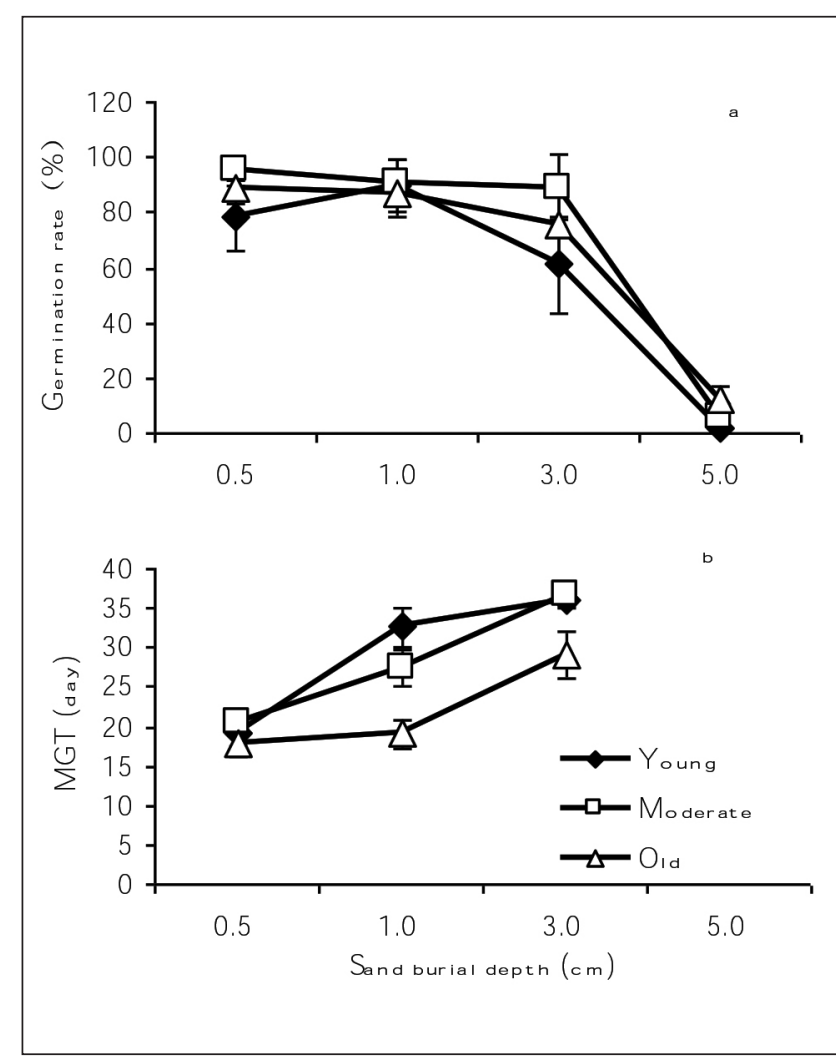

Fig. 3 Effects of sand burial and mother tree age on seed germination $\left(G_{r}\right.$ ) and mean germination time (MGT) of $P$. thumbergii. Values are means $\pm \mathrm{SD}$.

while MGT increased with the depth of burial (Fig. 3a). $G_{r}$ at $0.5 \mathrm{~cm}$ was similar to that at the $1.0 \mathrm{~cm}$ depth $(P=0.60)$ and both were greater than at $3.0 \mathrm{~cm}$ and $5.0 \mathrm{~cm}(P<0.01)$. The lowest $\mathrm{G}_{\mathrm{r}}$ appeared at the $5.0 \mathrm{~cm}$ depth. The difference of MGT among the depths was significant $(P<0.01)$ with an order of $0.5 \mathrm{~cm}<1.0 \mathrm{~cm}<3.0 \mathrm{~cm}$. Among the tree age classes, the $G_{r}$ in the youngest class (13-17 years) was significantly lower than those in the intermediate class (18-23 years) and mature class $(24-32$ years $)(P<0.05)$, while the difference between the intermediate and mature classes was not statistically significant $(P=0.21)$. A significant difference of MGT between the youngest and intermediate classes was not observed in this study $(P=$ $0.73)$, while both were significantly higher than the mature age class $(P<0.01)$. A significant interaction was found on MGT between burial depth and tree age (Table 2). With the depth of burial, the increase in MGT of mature class trees was slower than the other two age classes (Fig. 3b).

\section{Seedling biomass allocation}

Seedling biomass and biomass allocation (except SMR) were impacted significantly by both burial depth and tree age (Fig. 4, Table 2). Biomass decreased with increased burial depth (Fig. 4a). There was also a significant effect on biomass between burial depth and tree age (Table 2). Biomass of the mature age class decreased more slowly than the other age classes with the increase of depth (Fig. 4a). As depth increased, LMR decreased and RMR and root/shoot ratio increased, while SMR did not change. Among tree age classes, the order of seedling biomass was intermediate $<$ young $<$ mature $(P<$ 0.01 ). Both the LMR and RMR in the young age class were similar to those in the intermediate age class. However, the LMR in the young and intermediate age classes were lower than that in the mature age class $(P<0.01)$ and the RMR and root/shoot ratio in the young and intermediate age classes was higher than that in the mature age class $(P<0.05)$. The SMR in the young age class was significant higher than those in the intermediate and mature age classes $(P<0.01$; Table 2$)$.

\section{Seedling growth}

Significant effects of sand depth on $\operatorname{RGR}_{\mathrm{H}}(F=1.93, P=0.16)$ and $\mathrm{RGR}_{\mathrm{D}}$ were not found $(F=0.83, P=0.45$; Fig. 5). But $\mathrm{RGR}_{\mathrm{H}}(F=8.64, P<0.01)$ and $\mathrm{RGR}_{\mathrm{D}}(F=6.31, P<0.01)$ were impacted significantly by age classes. The $R_{G R}$ and $R G R_{D}$ in the youngest class were similar to the intermediate age class, and both were lower than those in the mature age class $(P<$ $0.05)$. However, there were no significant interactions between depth and age in $\operatorname{RGR}_{\mathrm{H}}(F=0.89 \bigotimes P=0.48)$ and $\operatorname{RGR}_{\mathrm{D}}(F=0.39, P=0.81)$.

\section{Discussion}

Determining how to regenerate coastal $P$. thungergii forests without altering current forest structure and composition and interrupting its protective function is crucial in coastal forest management (Zhu et al. 2003, 2012). Dense canopies, low soil moisture and thick litter and duff on the ground have long been believed to be the primary factors that hamper the regeneration of $P$. thungergii (Zhu et al. 2012). However, recent studies found that few seedlings were found in stands near the shoreline, despite having greater light intensity (Zhang et al. 2009). Besides high soil salinity, one potential factor overlooked before could be low seed density and sand burial as observed in our study. There were fewer seeds in the soil near the shoreline $(<200 \mathrm{~m})$, and moreover, more seeds were distributed in the $2-5 \mathrm{~cm}$ layer due to sand burial (Fig. 2). As demonstrated by the germination experiment, fewer seeds of $P$. thungergii could germinate at a depth $>3 \mathrm{~cm}$ (Fig. 3a). Therefore, low seed density and depth may contribute to the poor regeneration of $P$. thungergii forest near the
Table 2. Two- way ANOVA analyses of effects of sand burial, tree age and their interaction on seed germination and seedling biomass allocation of $P$. thumbergii

\begin{tabular}{|c|c|c|c|c|c|c|}
\hline \multirow[b]{2}{*}{ Variables } & \multicolumn{2}{|c|}{ Sand burial depth } & \multicolumn{2}{|c|}{ Tree age } & \multicolumn{2}{|c|}{$\begin{array}{l}\text { Sand burial depth } \\
\times \text { Tree age }\end{array}$} \\
\hline & $F$-value & P-value & $F$-value & P-value & $F$-value & P-value \\
\hline $\mathrm{G}_{\mathrm{r}}$ & 210.69 & $<0.01$ & 7.40 & $<0.01$ & 2.12 & 0.07 \\
\hline MGT & 212.34 & $<0.01$ & 58.98 & $<0.01$ & 13.19 & $<0.01$ \\
\hline Biomass & 32.32 & $<0.01$ & 24.22 & $<0.01$ & 3.27 & $<0.05$ \\
\hline LMR & 9.82 & $<0.01$ & 14.07 & $<0.01$ & 1.32 & 0.28 \\
\hline SMR & 1.27 & 0.29 & 10.76 & $<0.01$ & 0.63 & 0.64 \\
\hline RMR & 13.22 & $<0.01$ & 6.90 & $<0.01$ & 0.47 & 0.76 \\
\hline Root/shoot ratio & 13.62 & $<0.01$ & 6.72 & $<0.01$ & 0.57 & 0.69 \\
\hline
\end{tabular}



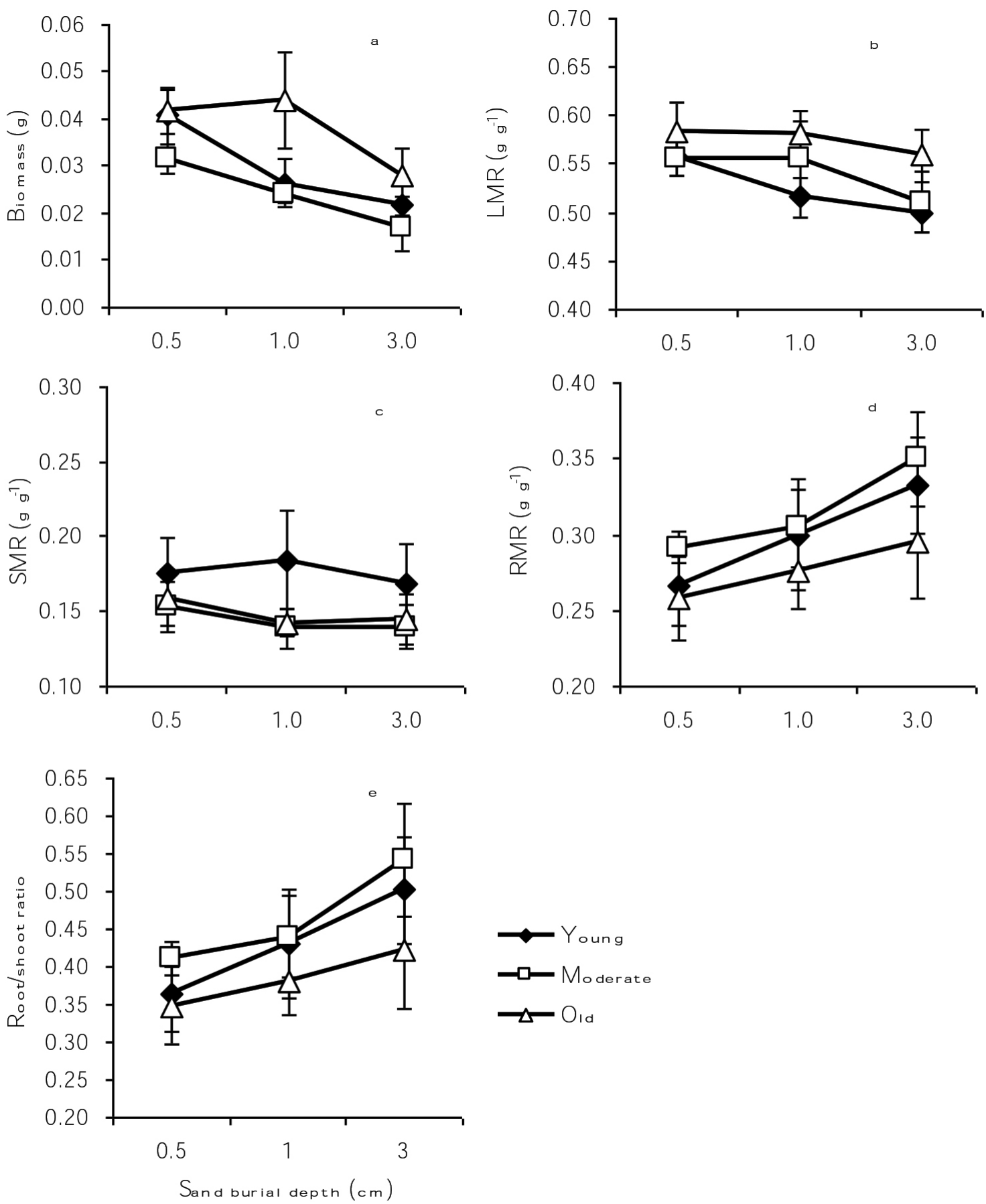

Fig.4. Effects of sand burial and mother tree age on seeding biomass allocation of $P$. thumbergii. Values are means $\pm \mathrm{SD}$.

shoreline. The concomitant relationship between soil seed bank and plant regeneration was also previously reported (Zhu and Wang 1992).

Burial depth influences seed germination and seedling establishment (Chen and Maun 1999, Redondo-Gómez et al. 2011, Zhu et al. 2014). Plant species respond differently to burial depths in seed germination (Chen and Maun 1999, Zheng et al. 2005, Li et al. 2007). In this study, P. thungergii seeds showed the greatest germination rates at depths of 0.5 and $1 \mathrm{~cm}$ (Fig. 3a). Liu et al. (2011) and Zhu et al. (2014) also found similar results and thought they were related to greater humidity (soil moisture) around these seeds in the top layer. The lowest seed germination rates at the $5 \mathrm{~cm}$ burial depth may be related to low oxygen in the sand (Vleeshouwers 1997) or the exhaustion of seed reserves during germination (Chen and Maun 1999, Liu et al. 2011). Thus, it could be 

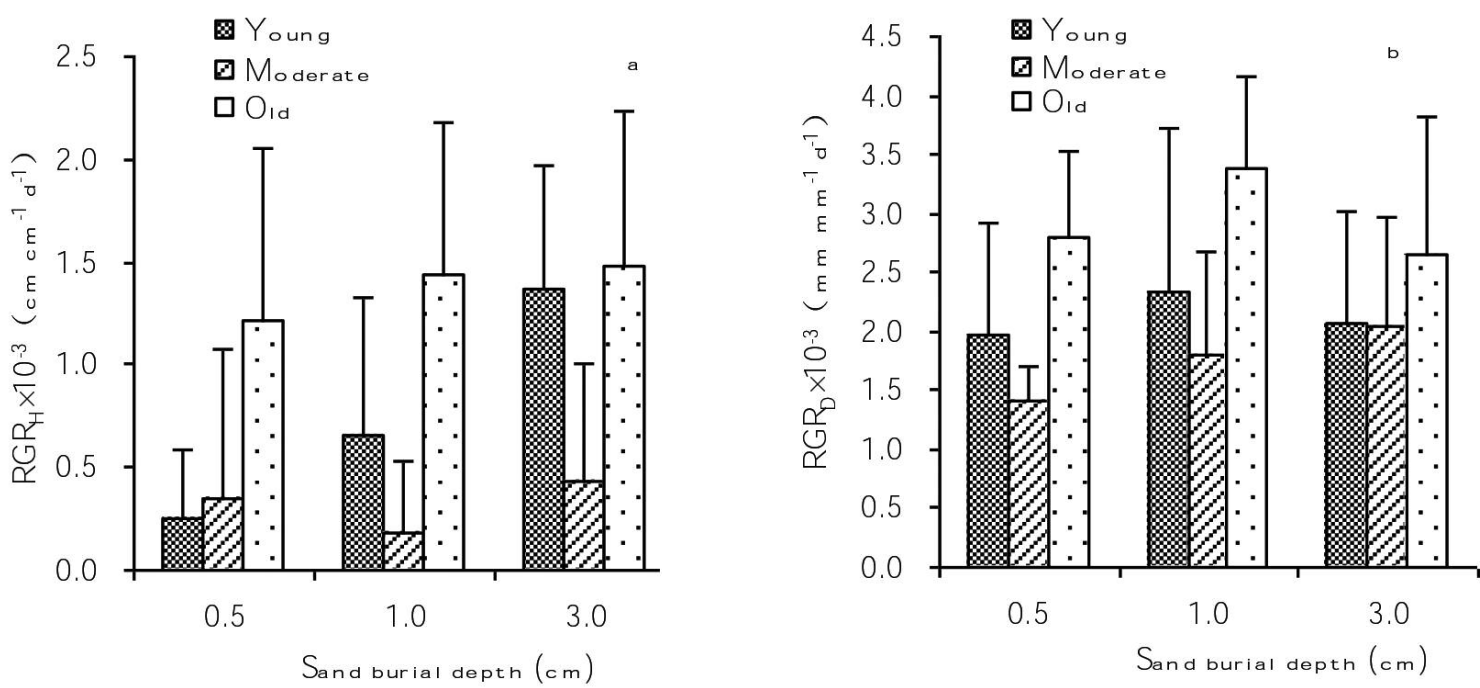

Fig.5. Effects of sand burial and mother tree age on seeding relative growth rate of $P$. thumbergii. Values are means \pm SD.

inferred that $P$. thungergii seeds could not germinate successfully at a depth $\geq 3 \mathrm{~cm}$. With an increase in depth, MGT increased (Fig. 3b), which was similar to Cyperus pitcher (Chen and Maun 1999) and C. capitatus Vand (RedondoGómez et al. 2011). The delayed germination will increase the chances of infection by seed borne and soil borne pathogens (Beckstead et al. 2010), related to low germination rates at approximately $5 \mathrm{~cm}$ depth.

Tree age significantly affected seed germination and has been reported in other studies. Germination rates for Sorbus torminalis (L.) (Espahbodi et al. 2007) and P. echinata Mill. Acc. (Grayson et al. 2002) increased at first and then declined with tree age. The maximum rate appeared in the intermediate age class $(30 \mathrm{~cm}$ class for $S$. torminalis and $33 \mathrm{~cm}$ class for P. echinata, respectively). Similarly, Lyngdoh et al. (2014) found that seeds collected from intermediate aged trees (i.e., 45 years old) of Livistona jinkensiana Griff. consistently had greater weight and germination rates compared to seeds collected from trees 18-35 years of age, and 54-74 years of age. However, the germination rate increased and MGT decreased monotonically with tree age of $P$. thungergii in this study (Fig. 3). Seed quality might be increased by ovule abortion rate of cones with increasing tree age (Mao et al. 2010). Besides high rates of embryo abortion in mature seeds of older Cistus albidus L., increasing salicylic acid, jasmonic acid and vitamin $\mathrm{E}$ levels also were important to ensure seed quality (Müller et al. 2014). Furthermore, we found significant interaction on MGT between depth and tree age. Age slowed down the rate of increase of MGT with the increase in depth. Cendán et al. (2013) thought optimizing the timing of germination was vital for seedling establishment in the natural environment. These results serve as an example of the complexity of seed germination in natural environments.

Biomass allocation patterns of plant species in different environmental conditions demonstrate their adaptive strategies (Poorter et al. 2012, Zheng et al.). High root biomass investment is an important adaptation for plants to survive under sand dune conditions (Gad et al. 2012). In this paper, we found RMR and root/shoot ratio increased with increased depth. When a plant is buried, soil moisture in the root zone increases and soil temperature decreases (Shi et al. 2004). Moreover, high root biomass allocation benefits water absorption (Perumal et al. 2006). However, some researchers reported that sand burial mainly increased aboveground biomass of seedlings (Gilbert and Ripley 2010, Xu et al. 2013a). High investment in stem biomass could increase stem elongation of seedlings, making them less vulnerable to burial (Brown 1997, Xu et al. 2013a). Frosini et al. (2012) did not find the root/shoot ratio of Sporobolus virginicus (L.) Kunth was affected significantly by sand burial. Sykes and Wilson (1990) reported six of 29 New Zealand sand dune species decreased root/shoot ratios with depth, four species did not change significantly, while 19 species increased root/shoot ratios. These results indicated biomass allocation responses to sand burial vary by species and their growing conditions. In this study, LMR increased with tree age (Fig. 4b). High investment in leaf biomass was advantageous for species to maintain high photosynthetic capacity and fast growth (Harris and Davy 1987, 1988; Zheng et al. 2012) and improve light interception ability in the understory (Poorter et al. 2012). The increase of leaf biomass investment with age is an important adaptive strategy for $P$. thungergii seedlings to respond to sand burial and low light.

Growth is used as a predictor because it integrates the effects of different stresses on species vigor and carbon balance (Pedersen 1998). Although seedling biomass decreased with an increase in depth at the beginning of the experiment, no significant differences were found at 0.5 to $3.0 \mathrm{~cm}$ depths at the end of the experiment (Fig. 5), indicating that partial burial might stimulate seedling growth. Many plant species enhanced seedling growth by partial burial compared to complete burial (Shi et al. 2004, Zheng et al. 2012). For 
instance, high soil moisture and low soil temperature around root zones by partial burial benefited water absorption and high leaf water content, which elevated the photosynthesis and growth of Ulmus pumila L. seedlings (Shi et al. 2004). Perumal and Maun (2006) postulated that the growth stimulation of partially buried seedlings was caused primarily by an increase in root growth. Plant species survival to sand burial could maintain a trade-off between height growth and mechanical stability (Niklas et al. 2006, Vospernik et al. 2010). Increased stem elongation could make plants more prone to wind-induced drag (Anten et al. 2005). However, this risk could be mitigated by increasing stem thickness at the same time (Goodman and Ennos 1996, Xu et al. 2013a), which increases the ability of plants to resist mechanical stress (Xu et al. 2013b). Both $\mathrm{RGR}_{\mathrm{H}}$ and $\mathrm{RGR}_{\mathrm{D}}$ in the mature age class were greater than those in the young and intermediate classes (Fig. 5), indicating advantages on both the growth of stem height and stem thickness. With the increase of tree age, the resistant ability to sand burial for $P$. thungergii seedlings increased. Moreover, high growth rates provide a competitive advantage for species to grow the competition of surrounding species (Toledo-Aceves and Swaine 2008). A higher growth rate is another important adaptive strategy for light demanding $P$. thungergii seedlings to respond to sand burial and low light conditions under the forest canopy.

Sand burial was an important stimulating factor on plant regeneration. However, suitable depths (e.g., $0.5-3.0 \mathrm{~cm}$ ) need to be determined for improved seed germination and seedling growth for species such as $P$. thunbergii. Overstory tree age of $P$. thunbergii exhibits a significant effect on seed regeneration and seedling growth as well. Older trees produced quality seeds with higher germination rates. Moreover, seedlings from these seeds showed high growth rates and light interception ability due to high leaf biomass investment. Large variation in seed germination and seedling growth among different age classes and burial depths suggests that other biotic and abiotic factors may also play an important role in $P$. thunbergii regeneration and growth. The interaction of tree age and burial depth with other limiting factors such as light intensity, soil moisture, and soil nutrients on natural regeneration should be addressed in future studies to better understand the natural regeneration processes of this species. Furthermore, light thinning is needed to improve the vigor and growing conditions of residual trees for the production of high quality seeds while maintaining the protective functions of these forests. Light thinning also has beneficial effects on the growth of ground vegetation and mitigation of excessive sand burial. While further research is necessary, resource managers can use the information and suggestions provided here to enhance regeneration rates of these forests as the function of dune forests is vital for the mitigation of damage to dune/coastal areas.

\section{Acknowledgments}

This research was financially supported by Yantai City Science and Technology Support Program of China (2012017), the National Natural Science Funds, China (No. 31370474) and Shandong Science and Technology Development Plan (2015GNC111026). Drs. Edward Loewenstein from Auburn University, Alabama, and Michael Crosby from Shorter University, Georgia helped reviewing this manuscript.

\section{References}

Alvarez, R., L. Valbuena and L. Calvo. 2005. Influence of tree age on seed germination response to environmental factors and inhibitory substances in Pinus pinaster. Int. J. Wildland Fire 14: 277-284. Available from: http://dx.doi.org/10.1071/WF04066

Anten, N.P.R., R. Casado-Garcia and H. Nagashima. 2005. Effects of mechanical stress and plant density on mechanical characteristics, growth, and lifetime reproduction of tobacco plants. Amer. Naturalist 166: 650-660. Available from: http://www.jstor.org/stable/1 $0.1086 / 497442$

Beckstead, J., S.E. Meyer, B.M. Connolly, M.B. Huck and L.E. Street. 2010. Cheatgrass facilitates spillover of a seed bank pathogen onto native grass species. J. Ecol. 98: 168-177. doi: 10.1111/j.13652745.2009.01599.x.

Brown, J.F. 1997. Effects of experimental burial on survival, growth, and resource allocation of three species of dune plants. J. Ecol. 85: 151-158. doi: 10.2307/2960647.

Cendán, C., L. Sampedro and R. Zas. 2013. The maternal environment determines the timing of germination in Pinus pinaster. Environ. Exp. Bot. 94: 66-72. doi:10.1016/j.envexpbot.2011.11.022.

Chen, H. and M.A. Maun. 1999. Effects of sand burial depth on seed germination and seedling emergence of Cirsium pitcher. Plant Ecol. 140: 53-60. doi: 10.1023/A:1009779613847.

Connor, K.F. and R.M. Lanner. 1994. Effects of tree age on pollen, seed, and seedling characteristics in Great Basin bristlecone pine. Bot. Gaz. 152: 107-113. Available from: http://www.jstor.org/stable/2995497

Espahbodi, K., S.M. Hosseini, H. Mirzaie-Nodoushan, M. Tabari, M. Akbarinia and Y. Dehghan-Shooraki. 2007. Tree age effects on seed germination in Sorbus torminalis. Gen. Appl. Plant Physiology 33: $107-119$.

Frosini, S., C. Lardicci and E. Balestri. 2012. Global change and response of coastal dune plants to the combined effects of increased sand accretion (burial) and nutrient availability. PLoS One 7: e47561. doi:10.1371/journal.pone.0047561.

Gad, M.R.M., M.E.A. EI-Hadidy and A.A.A. EI-Nabarawy. 2012. Comparative study on the adaptation of some natural plants grown under macronutrients limitation at North Sinai sand dunes (Egypt). Ann. Agr. Sci. 57: 81-90. doi:10.1016/j.aoas.2012.03.001.

Ganatsas, P., M. Tsakaldimi and C. Thanos. 2008. Seed and cone diversity and seed germination of Pinus pinea in Strofylia Site of the Natura 2000 Network. Biodivers. Conserv. 17: 2427-2439. doi: 10.1007/s10531-008-9390-8.

Gilbert, M.S. and B.S. Ripley. 2010. Resolving the differences in plant burial responses. Austral. Ecol. 35: 53-59. doi: 10.1111/j.14429993.2009.02011.x.

Goodman, A.M. and A.R. Ennos. 1996. A comparative study of the response of the roots and shoots of sunflower and maize to mechanical stimulation. J. Exp. Bot. 47: 1499-1507. doi: 10.1093/ $\mathrm{jxb} / 47.10 .1499$.

Grayson, K.J., R.F. Wittwer and M.G. Shelton. 2002. Cone characteristics and seed quality 10 years after an uneven-aged regeneration cut in shortleaf pine stands. Gen. Tech. Rep. SRS-48.

Guo, C., Z. Wang and J. Lu. 2010. Seed germination and seedling development of Prunus armeniaca under different burial depths in soil. J. Forest Res. 21: 492-496. doi: 10.1007/s11676-010-0104-1.

Harris, D. and A.J. Davy. 1987. Seedling growth in Elymus farctus after episodes of burial with sand. Ann. Bot. 60: 587-593. Available from: http://www.jstor.org/stable/42757877

Harris, D. and A.J. Davy. 1988. Carbon and nutrient allocation in Elymus farctus seedlings after burial with sand. Ann. Bot. 61: 147-157. Available from: http://www.jstor.org/stable/42770272

Hayasaka, D., K. Fujiwara and E.O. Box. 2009. Recovery of sandy beach and maritime forest vegetation on Phuket Island (Thailand) after the major Indian Ocean tsunami of 2004. Appl. Veg. Sci. 12: 211-224. doi: 10.1111/j.1654-109X.2009.01017.x. 
Li, Q., W. Zhao and H. Fang. 2007. Adaptation of Nitraria sphaerocarpa to wind-blown sand environments at the edge of a desert oasis J. Environ. Sci. 19: 482-487. doi:10.1016/S1001-0742(07)60081-3.

Liu, H., X. Shi, J. Wang, L. Yin, Z. Huang and D. Zhang. 2011. Effects of sand burial, soil water content and distribution pattern of seeds in sand on seed germination and seedling survival of Eremosparton songoricum (Fabaceae), a rare species inhabiting the moving sand dunes of the Gurbantunggut Desert of China. Plant Soil 345: 69-87. doi: 10.1007/s11104-011-0761-7.

Lyngdoh, N., M. Kumar, N. Kumar and A.K. Pandey. 2014. Effects of age of plantation on seed characters and growth performance of Tokopatta (Livistona jinkensiana Griff.) seedling. J. Appl. \& Nat. Sci. 6: 672-676.

Mao, P., G. Han, Z. Zhang, G. Wang, J. Yu, J. Xu and B. Cao. 2010. Relationship between distribution of diameter size classes and characteristics of cones and seeds of Pinus thunbergii in coastal protection forest. J. Ne. Forest Univ. 38: 21-23. (Chinese with English abstract).

Maun, M.A. 1994. Adaptations enhancing survival and establishment of seedlings on coastal dune systems. Vegetatio 111: 59-70. doi: $10.1007 / B F 00045577$.

Müller, M., L. Siles, J. Cela and S. Munné-Bosch. 2014. Perennially young: seed production and quality in controlled and natural populations of Cistus albidus reveal compensatory mechanisms that prevent senescence in terms of seed yield and viability. J. Exp. Bot. 65: 287-297. doi: 10.1093/jxb/ert372.

Niklas, K.J., E.D. Cobb and T. Marler. 2006. A comparison between the record height-to-stem diameter allometries of Pachycaulis and Leptocaulis species. Ann. Bot. 97: 79-83. doi: 10.1093/ aob/mcj002.

Pedersen, B.S. 1998. The role of stress in the mortality of Midwestern oaks as indicated by growth prior to death. Ecology 79: 79-93. doi: $10.2307 / 176866$

Perumal, V.J. and M.A. Maun. 2006. Ecophysiological response of dune species to experimental burial under field and controlled conditions. Plant Ecol. 184, 89-104. doi: 10.1007/s11258-005-9054-7.

Poorter, H., K.J. Niklas, P.B. Reich, J. Oleksyn, P. Poot and L. Mommer. 2012. Biomass allocation to leaves, stems and roots: metaanalyses of interspecific variation and environmental control. New Phytol. 193: 30-50. doi: 10.1111/j.1469-8137.2011.03952.x.

Raccuia, S.A., V. Cavallaro and M.G. Melilli. 2004. Intraspecific variability in Cynara cardunculus L. var. sylvestris Lam. Sicilian populations: seed germination under salt and moisture stresses. J. Arid Environ. 56: 107-116. doi:10.1016/S0140-1963(03)00006-5.

Redondo-Gómez, S. L. Andrades-Moreno, R. Parra, E. MateosNaranjo and A.M. Sánchez-Lafuente. 2011. Factors influencing seed germination of Cyperus capitatus, inhabiting the moving sand dunes in southern Europe. J. Arid Environ. 75: 309-312. doi:10.1016/j.jaridenv.2010.10.014.

Shi, L., Z.J.Zhang, C.Y. Zhang and Z. Zhang. 2004. Effects of sand burial on survival, growth, gas exchange and biomass allocation of Ulmus pumila seedlings in the Hunshandak Sandland, China. Ann. Bot. 94: 553-560. doi: 10.1093/aob/mch174.

Sykes, M.T. and J.B. Wilson. 1990. An experimental investigation into the response of New Zealand sand dune species to different depths of burial by sand. Acta. Bot. Neer. 39: 17-181. doi: 10.1111/ j.1438-8677.1990.tb01485.x

Taniguchi, T., S. Tamai, N. Yamanaka and K. Futai. 2007. Inhibition of the regeneration of Japanese black pine (Pinus thunbergii) by black locust (Robinia pseudoacacia) in coastal sand dunes. J. For. Res. 12: 350-357. doi: 10.1007/s10310-007-0023-y.
Toledo-Aceves, T. and M.D. Swaine. 2008. Above- and belowground competition between the liana Acacia kamerunensis and tree seedlings in contrasting light environments. Plant Ecol. 196: 233-244. doi: 10.1007/s11258-007-9347-0.

Vleeshouwers, L.M. 1997. Modeling the effect of temperature, soil penetration resistance, burial depth and seed weight on pre-emergence growth of weeds. Ann. Bot. 79: 553-563. doi: 10.1006/anbo/ 79.5.553.

Vospernik, S., R.A. Monserud and H. Sterba. 2010. Do individualtree growth models correctly represent height: diameter ratios of Norway spruce and Scots pine? Forest Ecol. Manage. 15: 1735-1753. doi:10.1016/j.foreco.2010.07.055.

Xu, J., Q. Li, W. Wang and X. Gou. 2003. Studies on the protective maturity period and regeneration age of Pinus thunbergii protection forest on sandy coast, Shandong province. Sci. Silvae Sin. 39: 91-97. (Chinese with English abstract).

Xu, L., H. Huber, H.J. During, M. Dong and N.P.R. Anten. 2013a. Intraspecific variation of a desert shrub species in phenotypic plasticity in response to sand burial. New Phytol. 199: 991-1000. doi: 10.1111/nph.12315.

Xu, L., F.Yu, M. Werger, M. Dong and N.P.R. Anten. 2013b. Interactive effects of mechanical stress, sand burial and defoliation on growth and mechanical properties in Cynanchum komarovii. Plant Biology 15: 126-134. doi: 10.1111/j.1438-8677.2012.00629.x.

Zhang, J. and M.A. Maun. 1994. Potential for seed bank formation in seven Great Lakes sand dune species. Amer. J. Bot. 81: 387-394. Available from: http://www.jstor.org/s

12445486

Zhang, Z., G. Han, P. Mao, G. Wang and Q. Xue. 2009. Effects of adult tree density, distance to coast and understory on natural regeneration of Pinus thunbergii coastal protection forest in Yantai Region. J. Natur. Resour. 24: 782-790. (Chinese with English abstract).

Zheng, M., L. Lai, L. Jiang, P. An, Y. Yu, Y. Zheng, H. Shimizu, J.M. Baskin and C.C. Baskin. 2012. Moderate water supply and partial sand burial increase relative growth rate of two Artemisia species in an inland sandy land. J. Arid Environ. 85: 105-113. doi:10.1016/ j.jaridenv.2012.05.006.

Zheng, Y., Z. Xie, Y. Yu, L. Jiang, H. Shimizu and G.M. Rimmington. 2005. Effects of burial in sand and water supply regime on seedling emergence of six species. Ann. Bot. 95: 1237-1245. doi: 10.1093/aob/mci138

Zhu, J., T. Matsuzaki, F. Li and Y. Gonda. 2003. Effect of gap size created by thinning on seedling emergency, survival and establishment in a coastal pine forest. Forest Ecol. Manage. 182: 339-354. doi:10.1016/S0378-1127(03)00094-X.

Zhu, J., Y. Gonda, L. Yu, F. Li, Q. Yan and Y. Sun. 2012. Regeneration of a coastal pine (Pinus thunbergii Parl.) forest 11 years after thinning, Niigata, Japan. Plos One 7: e47593. doi: 10.1371/journal .pone.0047593.

Zhu, N. and Y. Wang. 1992. Reproductive ecological studies of Acanthopanax senticosus (II)-seed dispersal, seed bank and recruitment. J. Ne. Forest Univ. 20: 12-17. (Chinese with English abstract). Zhu, Y., M. Dong and Z. Huang. 2009. Response of seed germination and seedling growth to sand burial of two dominant perennial grasses in $\mathrm{Mu}-\mathrm{Us}$ sandy grassland, semiarid China. Rangel Ecol. Manag. 62: 337-344. doi: http://dx.doi.org/10.2111/07-072.1.

Zhu, Y., X.Yang, C.C. Baskin, J.M. Baskin, M. Dong, and Z. Huang. 2014. Effects of amount and frequency of precipitation and sand burial on seed germination, seedling emergence and survival of the dune grass Leymus secalinus in semiarid China. Plant Soil 374: 399-409. doi: 10.1007/s11104-013-1892-9 